\title{
The New Abundance of Policy Advice: The Advisory Roles of Political Scientists in Norway
}

Ivar Bleiklie and Svein Michelsen

\subsection{INTRODUCTION}

This chapter investigates the position of academic policy advice in Norway, and in particular the role played by political scientists in policy advice. To inform the presentation of the particularities of the Norwegian case, we base our analysis on the locational model of policy advisory systems (PAS), arenas and roles (Chap. 2), as well as on previous studies of politicoadministrative systems and Scandinavian administrative traditions (Pollitt \& Bouckaert, 2004; Painter \& Peters, 2010a, b). We identify structures and processes in the provision of political science expert advice in Norway. Norwegian academic political scientists are heavily engaged in policy advice, at various levels of government as well as in public debate on relevant issues. We ask the following questions. How is the Norwegian policy advisory system to be understood? What are the main access points for certified academics wishing to bring their expertise to policymaking? What

I. Bleiklie $(\bowtie) \bullet S$. Michelsen

University of Bergen, Bergen, Norway

e-mail: Ivar.Bleiklie@uib.no; Svein.Michelsen@uib.no

(C) The Author(s) 2022

M. Brans, A. Timmermans (eds.), The Advisory Roles of Political

Scientists in Europe, https://doi.org/10.1007/978-3-030-86005-9_11 
trends can be discerned? What is the position of Norwegian political scientists in emerging structures and processes of policy advice? We examine the policy advice offered by political scientists who have certified academic credentials and who are researchers in universities or specialized research institutions. We pinpoint two important corporatist arenas for strong involvement in policy advice: the Research Council of Norway (RCN) and ad hoc advisory bodies.

To answer these questions, we combine data based on responses from political scientists in a pan-European survey, conducted in connection with COST Action CA15207, on the Professionalization and Social Impact of European Political Science: the survey, and hence the data, concerns norms of engagement, types of advice, relations with other actors and arenas for the provision of policy advice. We also use data collected regarding the development of political science as an academic discipline in Norway. Taken together, the data point towards a new abundance of policy advice, as well as a strengthening of the position of political scientists in the national policy advisory system, in different ways and in different areas.

\subsection{Theoretical Perspectives on Policy Advisory Roles, Arenas and Systems}

What is policy advice? What place does it have in decision-making processes in modern democracies? The concept of "policy advisory systems" (PAS) represents a new way of characterizing and analysing multiple sources of policy advice utilized by governments in policymaking (Craft \& Howlett, 2013). A PAS may be described as nationally specific ways of soliciting, organizing and delimiting policy advice activities. PAS literature maintains that advisory systems have changed as a result of the dual effects of the two processes of "politicization" and "externalization". Politicization refers to the increased use of partisan political advice inside government itself; the strengthening of political acumen; the rising numbers and roles of political appointees in the executive; and the hiring of ministerial advisors to aid elected representatives. Externalization is the process whereby the locus of policy advice shifts from within the public bureaucracy to outside sources. PAS literature argues that these twin dynamics have blurred the traditional sharp distinctions between inside and outside 
sources of advice and between the technical and political dimensions of policy formulation.

We argue that there is a need to extend the focus of attention from Anglo-Saxon political systems to also include European corporatist systems like Norway, in which policymaking is enmeshed in networks of organized interests and consultative obligations. Corporatist systems are ambiguous. Corporatist organizational arrangements may serve to contain political conflict and usually mean de-politicization. However, they may also be a potential instrument of political control. The balance between the two uses might vary, depending on the character of the corporatist system, its location and its function in the politico-administrative system (Streeck \& Schmitter, 1985). Corporativization also varies over time. One important question is whether, and to what extent, corporatist systems can serve as instruments for expert advice and the force of knowledge-based arguments or primarily as bargaining arenas.

The dynamics of policy formulation and the role of policy advice are continuously subjected to movements of political interest or control beyond previously accepted lines (Starr \& Immergut, 1987: 221). As the state has expanded, the space for politics has become increasingly restricted in a number of policy areas, and many issues are now discussed in technical, rather than political, terms. Thus, a process of de-politicization has taken place through bureaucratization as well as professionalization and corporativization. This has left policy advice and decision-making authority to the discretion of bureaucrats, professional experts or interest groups. The interaction of politicization and de-politicization might produce very different advisory arenas, structures and dynamics and change the locus of policy advice in the internal government arena, as well as in the overlapping and external arenas.

We argue that the PAS may fruitfully accommodate the participation of certified expertise located in academic knowledge-producing institutions and their roles in the provision of policy advice. Starting with three partly overlapping arenas-the Government, the Academic and the Societal arenas - the location of advisory actors can be identified (adapted from Blum \& Brans, 2017; see Chap. 2, this volume).

The three arenas can be seen as demarcations between science and nonscience, between science and politics as well as between the lay area and the policy area. Political scientists can act in, and move between, all three arenas. They can act as members of the scientific community in the academic arena, as academic experts in the societal, lay arena, or they can act 
as bureaucratic experts in the government arena. The boundaries between these areas are not just important in functional terms but invite us to take the relations between arenas as entry points for the analysis of policy advice seriously. The notion of Overlapping areas is potentially very useful for studying demarcations between political and scientific tasks in advisory relationships as well as their interrelations. Several spaces and institutions for transmitting scientific knowledge to politically useful knowledge-as indicated above-have evolved at the intersections between the three arenas. These arenas provide space for the formation of a variety of advisory roles and activities, where political scientists engage in advisory bodies, as members of public commissions and boards, or in mass media of various types and forms.

We distinguish between different advisory roles and the types of knowledge that may underpin them. These roles can be illuminated by a set of ideal types (Weber, 2013) that allow the broad classification of advisory roles, based on the different kinds of knowledge that underpin them (Table 11.1).

The Pure Academic is a researcher who primarily fulfils a duty to society by informing politicians or society at large about his or her research, broadly in the enlightenment tradition. The Expert is an academic more focused on producing scientific knowledge and technical advice to help understand and/or develop practical solutions to problems defined by decision-makers. The Opinionating scholar uses academic knowledge to draw implications from normative positions in political theory relating to current affairs or to justify normative stances in terms of political science data and empirical analyses. The Public Intellectual is a well-known, recognized, learned person whose written works and other social and cultural contributions are recognized by many members of society in general.

Table 11.1 Advisory roles and types of knowledge

\begin{tabular}{|c|c|}
\hline Advisory Role & Type of Knowledge \\
\hline The Pure Academic & Scientific (episteme) \\
\hline The Expert & $\begin{array}{l}\text { Scientific or applied (what } \\
\text { works) (techne) }\end{array}$ \\
\hline The Opinionating scholar & $\begin{array}{l}\text { Opinionated normative } \\
\text { science (phronesis) }\end{array}$ \\
\hline The Public Intellectual & Episteme, Techne and Phronesis \\
\hline
\end{tabular}

Source: Chapter 2, this volume 
Traditionally, in public administration the importance and contribution of policy advice was strongly related to that of the expert, technical expertise provided based on specialized knowledge. The addition of other types of advisory roles, like the opinionating scholar, the public intellectual and the pure academic, allows a more diverse set of activities to be explored, which may be defined as advisory in an extended sense and which take place in a variety of arenas.

The combination of the locational model and the policy advisory ideal types enables us to get a firmer grip on relations between the different arenas, different types of advisory roles and activities associated with these role types. However, different nation states with their peculiar politicoadministrative systems and administrative traditions have developed different habitats and structural peculiarities that may help us understand the distribution of advisory roles across arenas, as well as the nature of the different arenas in which policy advice is provided. In the next section, the central characteristics of the Norwegian PAS system are presented and discussed.

\subsection{The Configuration of the Norwegian Policy ADVISORY SYSTEM}

Until now the Norwegian political administrative system has not been mapped as a PAS with its dynamics, governmental and non-governmental actors. Nor is there very much literature available on the policy advisory role of political scientists. Therefore, we have had to make do with other sources in order to approach the topic. Our point of departure is the literature on politico-administrative regimes and administrative traditions, concepts that refer to fundamentals of political life that are relatively stable and that change only infrequently or gradually (Pollitt \& Bouckaert, 2004; Verhoest et al., 2010; Bleiklie \& Michelsen, 2013; Painter \& Peters, 2010a). We assume that the character of the PAS in any nation state is broadly shaped by regime type. Scandinavian administrative traditions combine the Rechtsstaat tradition of the state as an integrating force focused on the preparation and enforcement of law, with a strong universal welfare orientation (Painter \& Peters, 2010b). The Scandinavian countries are regarded as unitary states, both centralized and also decentralized (Baldersheim \& Rose, 2010), where the central bureaucracy enjoys a strong position (Olsen, 1983) and where state-society relations have been 
characterized by corporatism as well as extensive participatory networks (Painter \& Peters, 2010b; Peters 2001). These systems typically combine a strong, responsible bureaucracy with a complex institutionalized landscape consisting of corporatist and advisory bodies organized in different shapes and forms.

The Norwegian politico-administrative regime may be considered as a complex combination of partly conflicting principles and organizational structures. It has a long tradition of homogenous, parliamentary-based political leadership where major actors have coexisted peacefully (Olsen, 1983). The political leadership has maintained a close relationship with administrative leadership, characterized by strong mutual trust. Central political and administrative actors have agreed on balancing political considerations with a rule-oriented civil service, citizens' rights, transparency, equality, the interests of affected parties and codes of professional behaviour. The Norwegian parliament has traditionally been based on modest forms of professionalization. Policy capacity has been weak, although somewhat strengthened in recent years (Askim et al., 2014). During the 1980s and 1990s, Parliament strengthened its position vis-à-vis the executive (Rommetvedt, 2005), primarily due to a transition from majority to minority governments. This development has turned parliament into an attractive arena for "lobbying" and the provision of policy advice (Espeli, 1999). The number of ministries has remained relatively constant over time, but relations between them have changed, often because of government reshuffles. By international standards, Norwegian ministries are relatively small, and their capacity for policymaking, reform and control is relatively low (Verhoest et al., 2010). Furthermore, the ministries have been streamlined over time, as tasks have been offloaded onto other institutions. An important justification for this development has been the need to transform the ministries into political secretariats for the minister, by devolving routine tasks to subordinate agencies. The combination of these features clearly indicates that the ministries are very important in the provision of policy advice and a key part of the PAS structure.

However, there is also a strong tradition of internal devolution or agentification going back to the nineteenth century (Jacobsen, 1964). These processes have opened up spaces for the integration of expert knowledge considered practically useful for continuous political problem-solving (Jacobsen, 1960). Thus, the Norwegian central administration has come to comprise a more varied set of knowledge groups than the classical lawdominated format associated with its inception. This has also opened up 
the way for continuous links to problem-driven research activities. Other important aspects can be related to the rise of the research councils. In this type of arena, the role of organized research as a tool for providing policy advice to the central government has been developed and honed through a merger, in 1994, into a single research council, situating all research into a context of application. At the same time, public commissions and advisory bodies have evolved into arenas in which academic experts play an increasingly important part. The de-centralization and delegation of public authority and responsibility to local government has expanded with the growth of welfare state services, far more than central government has. In $1962,50 \%$ of those working full-time in the public administration were employed by local government bodies; the corresponding figure in 2001 was $74 \%$. The fact that most welfare state services are delivered by local government probably impacts the structuring of policy advice.

Ongoing changes in the Norwegian PAS can also be related to processes of pluralization (Rommetvedt, 2005). The Norwegian corporatist system has been characterized as highly specialized and segmented, that is, as sectorized concentrations of power. Cleavages do not run between the central bureaucracy and organized interests as different types of institutions but between different constellations of institutions. Political segments bear a resemblance to meso-concepts like "policy communities" or "policy networks", normally defined in terms of the basic values and perceptions shared by their participants, who may come from ministries, parliamentary committees, interest organizations and research institutions (Egeberg et al., 1978; Olsen, 1983). Within such segments, political advice may be based on shared values and may focus on technical criteria and means-end relations in political problem-solving. Arenas for integrated participation are mainly stable, and there is a focus on uncertainty avoidance and mutual trust rather than on appeals to the public with regard to matters of contention. In other areas where shared basic values are far from obvious, conflict levels may be higher, participation patterns much more fluid, and appeals to the public more recurrent. Rommetvedt (2005) holds that Norway has moved from a neo-corporatist system in the 1950s and 1960s, via a segmented state system in the 1970 s, to a neo-pluralist system in the $1980 \mathrm{~s}$ and 1990s. Twenty years into the twenty-first century, the Norwegian system looks like a mixture of elements of neo-corporatism, segmentation and neo-pluralism. The balance varies across sectors and policy areas, but the centre of gravity has probably moved in the direction of pluralism. Even if these characteristics are important, they cannot easily explain the 
position of political science in the articulation of policy advice in Norway. In the next section, we present data on the national disciplinary traditions and advisory roles of political scientists. This may provide a more precise understanding of how political scientists fit into the broader picture presented above.

\subsection{The Policy Advisory Roles of Expert Political SCIENTISTS}

Political science is a relatively new discipline that emerged in Norway, as in the rest of Europe, after WWII (Hammerstein, 2011). New social science disciplines emerged during that same period. The rise of the social sciences in Norway took place through a process of dual institutionalization. The first form of institutionalization consisted in the establishment of the Institute of Social Research, followed by the University of Oslo, with a study programme in political science; this was followed by the establishment of new positions, as well as a separate department, in political science (Thue \& Helsvig, 2011). The study of policy, political systems and social organizations previously undertaken primarily by history and law scholars at the university took on a new face. During the initial phase, the discipline led a modest existence characterized by internal dynamics (Kuhnle, 1986). The 1970s and 1980s represented an important period of expansion, during which political science secured a solid academic position at the country's four universities (Oslo, Bergen, Trondheim and Tromsø), as well as importance in the labour market. Political science became a favoured educational path for those aiming for a career in public administration, strengthening the utility and professionally oriented dimension of the discipline and the problem-driven aspects of research (Olsen, 2012). As the discipline grew and diversified, Norwegian political science emerged as empirically solid, nationally oriented, but not very innovative from a conceptual perspective (Olsen, 2012).

Today, the history of political science in Norway can safely be described as representing the transition from an individual pursuit to a collective enterprise. A review carried out in 2017 on behalf of the ProSEPS project revealed that the Norwegian political science community comprised 340 members (120 women and 220 men), located in 32 different institutions. The institutional landscape in which political scientists are employed has evolved from one university and one institution for applied science into 19 
universities, specialized universities and university colleges, together with 15 independent applied social research institutes. The University of Oslo and the University of Bergen represent the two strongholds of the discipline, where close to $70 \%$ of Norway's political scientists work. As far as sub-disciplines are concerned, Norwegian political science is heavily concentrated within comparative politics, public policy and administration. The field of international relations is considerably smaller, while political theory comprises a mere $4 \%$ of the political science community. A strong feature of the Norwegian Political Science profile is its policy-oriented research (SAMEVAL, 2018). A general observation covering most of the research areas is that much work is driven by a strong focus on Norwegian policy-related issues rather than on political science's theoretical development.

\subsubsection{Normative Views on Advisory Activities and Public Debate}

The Pan-European survey provides data on the perceptions of political scientists of a broad range of policy advice indicators and questions. This allows us to close in on the various roles that exist for the provision of policy advice. This section gives an overview of (a) attitudes among political scientists at the national level regarding involvement in policy advice and other forms of engagement in politics (Table 11.2), (b) their experiences of engagement in various policy-related activities (Table 11.3), (c) how frequently various channels for the provision of policy advice and/or consulting services are used (Table 11.4) and (d) the actors with whom they have engaged (Table 11.5), as well as the policy level at which engagement has taken place (Table 11.6). The Norwegian rate of response to the survey was only $18 \%$, which calls for a certain degree of caution when interpreting findings.

A large majority (more than 90\%) agree that political scientists have a professional duty to engage in public debate. Whether such activities are useful for expanding career options or not seems to be of lesser importance. The survey also indicates that research produced by political scientists is visible in public debate. More than $90 \%$ of respondents agree that political science is either very or quite visible in public debate, but not necessarily more so than other fields of knowledge. More than two-thirds of respondents have taken part in a public media debate over the last three years. Much of the media coverage has focused on the elections, although 
Table 11.2 Normative views on policy advice \% (N)-Norway

\begin{tabular}{|c|c|c|c|c|c|}
\hline & $\begin{array}{l}\text { Fully } \\
\text { agree }\end{array}$ & $\begin{array}{l}\text { Somewhat } \\
\text { agree }\end{array}$ & $\begin{array}{l}\text { Somewhat } \\
\text { disagree }\end{array}$ & $\begin{array}{l}\text { Fully } \\
\text { disagree }\end{array}$ & Missing \\
\hline $\begin{array}{l}\text { Political scientists should become } \\
\text { involved in policymaking }\end{array}$ & $\begin{array}{l}14.9 \\
(9)\end{array}$ & $35.8(23)$ & 29.9 (19) & $11.9(8)$ & $7.5(5)$ \\
\hline $\begin{array}{l}\text { Political scientists have a professional } \\
\text { obligation to engage in public } \\
\text { debate }\end{array}$ & $\begin{array}{l}35.8 \\
(23)\end{array}$ & $46.3(29)$ & $9.0(6)$ & $1.5(1)$ & $7.5(5)$ \\
\hline $\begin{array}{l}\text { Political scientists should provide } \\
\text { evidence-based knowledge and } \\
\text { expertise outside academia but not } \\
\text { directly involved in policymaking }\end{array}$ & $\begin{array}{l}31.3 \\
(20)\end{array}$ & $31.3(20)$ & $20.9(13)$ & $7.5(5)$ & $9.0(6)$ \\
\hline $\begin{array}{l}\text { Political scientists should refrain } \\
\text { from direct engagement with policy } \\
\text { actors }\end{array}$ & $\begin{array}{l}4.5 \\
(3)\end{array}$ & $3.0(2)$ & $29.9(19)$ & $\begin{array}{l}55.6 \\
(36)\end{array}$ & $6.04)$ \\
\hline $\begin{array}{l}\text { Political scientists should engage in } \\
\text { public debate since this is part of } \\
\text { their role as social scientists }\end{array}$ & $\begin{array}{l}62.7 \\
(40)\end{array}$ & $31.3(20)$ & $3.0(2)$ & 0 & $3.0(2)$ \\
\hline $\begin{array}{l}\text { Political scientists should engage in } \\
\text { media or political advisory activities } \\
\text { only after testing their ideas in } \\
\text { academic outlets }\end{array}$ & $\begin{array}{l}7.5 \\
(5)\end{array}$ & $23.9(15)$ & $43.3(28)$ & $\begin{array}{l}17.9 \\
(11)\end{array}$ & $7.5(5)$ \\
\hline $\begin{array}{l}\text { Political scientists should engage in } \\
\text { public debate because this helps } \\
\text { them to expand their career options }\end{array}$ & $\begin{array}{l}6.0 \\
(4)\end{array}$ & $23.9(15)$ & $31.3(20)$ & $\begin{array}{l}26.9 \\
(17)\end{array}$ & $\begin{array}{l}11.9 \\
(8)\end{array}$ \\
\hline
\end{tabular}

Source: ProSEPS survey data

Notes: Question: “To what extent do you agree with each of the following statements?” $N=63$

attention has also been given to various aspects of the public administration and the implementation of public sector reforms, as well as to international relations and foreign affairs. The strong focus on public debate reinforces the impression of a well-established, enduring aspect of Norwegian political science, namely, its focus on the general basis for democracy in Norwegian society (Underdal, 2007). Norwegian political scientists have a penchant for discussing democratic problems and the definition of such problems rather than their solutions, and there is not much evidence to suggest a movement towards a more practice-oriented profile within the discipline (Olsen, 2012). The more important effects are perhaps more indirect, although potentially of great significance. As a result of political science knowledge production, a whole vocabulary on 
Table 11.3 Frequency and type of advice $\%(N)$-Norway

\begin{tabular}{|c|c|c|c|c|c|c|}
\hline & $\begin{array}{l}\text { At } \\
\text { least } \\
\text { once a } \\
\text { week }\end{array}$ & $\begin{array}{l}\text { At least } \\
\text { once a } \\
\text { month }\end{array}$ & $\begin{array}{l}\text { At } \\
\text { least } \\
\text { once a } \\
\text { year }\end{array}$ & $\begin{array}{l}\text { Less } \\
\text { frequently }\end{array}$ & Never & Missing \\
\hline $\begin{array}{l}\text { I make value judgements and } \\
\text { normative arguments }\end{array}$ & $1.5(1)$ & $1.5(1)$ & $\begin{array}{l}13.4 \\
(9)\end{array}$ & $38.8(25)$ & $\begin{array}{l}35.8 \\
(23)\end{array}$ & $9.0(6)$ \\
\hline $\begin{array}{l}\text { I evaluate existing policies, } \\
\text { institutional arrangements, and } \\
\text { so on }\end{array}$ & $1.5(1)$ & $6.0(4)$ & $\begin{array}{l}46.3 \\
(29)\end{array}$ & $22.4(14)$ & $\begin{array}{l}16.4 \\
(10)\end{array}$ & $7.5(5)$ \\
\hline $\begin{array}{l}\text { I provide data and facts about } \\
\text { policies and political } \\
\text { phenomena }\end{array}$ & 0 & $10.4(7)$ & $\begin{array}{l}53.7 \\
(34)\end{array}$ & $19.4(12)$ & $\begin{array}{l}10.4 \\
(7)\end{array}$ & $6.0(4)$ \\
\hline $\begin{array}{l}\text { I analyse and explain the causes } \\
\text { and consequences of policy } \\
\text { problems }\end{array}$ & 0 & $9.0(6)$ & $\begin{array}{l}55.2 \\
(35)\end{array}$ & $20.9(13)$ & $\begin{array}{l}9.0 \\
(6)\end{array}$ & $6.0(4)$ \\
\hline $\begin{array}{l}\text { I offer consultancy services and } \\
\text { advice and make } \\
\text { recommendations on policy } \\
\text { alternatives }\end{array}$ & 0 & $4.5(3)$ & $\begin{array}{l}25.4 \\
(16)\end{array}$ & $35.8(23)$ & $\begin{array}{l}26.9 \\
(17)\end{array}$ & $7.5(5)$ \\
\hline $\begin{array}{l}\text { I make forecasts and/or carry } \\
\text { out polls }\end{array}$ & 0 & 0 & $6.0(4)$ & $20.9(13)$ & $\begin{array}{l}62.7 \\
(40)\end{array}$ & $\begin{array}{l}10.4 \\
(7)\end{array}$ \\
\hline
\end{tabular}

Source: ProSEPS survey data

Notes: Question: "How often, on average, during the last three years, have you engaged in any of the following advisory activities with policy actors (policymakers, ministry officials, interest groups, political parties, etc.)?”

$N=63$

elections, centring on "political cleavages", has been disseminated to, and shared with, the public at large. In the area of public administration, notions of the "segmented state", "the parliamentary chain of command", "new public management (NPM)", "wicked problems" and the significance of organization as a basis for political life and of political outcomes have permeated Norwegian public debate as well as the Civil Service and local government. Although difficult to measure, this vocabulary has been influential in structuring outlooks, perceptions and debate.

The general norm among political scientists is that one should not participate as an expert in public debate unless one has relevant and visible expertise in the field in question, as demonstrated by academic publications in the field. Few, if any, political scientists operate as public intellectuals rather than scientific experts with specialized knowledge in a policy 
Table 11.4 Channels and modes of advice dissemination \% (N)-Norway

\begin{tabular}{|c|c|c|c|c|c|c|}
\hline & $\begin{array}{l}\text { At least } \\
\text { once a } \\
\text { week }\end{array}$ & $\begin{array}{l}\text { At least } \\
\text { once a } \\
\text { month }\end{array}$ & $\begin{array}{l}\text { At least } \\
\text { once a } \\
\text { year }\end{array}$ & $\begin{array}{l}\text { Less } \\
\text { frequently }\end{array}$ & Never & missing \\
\hline \multicolumn{7}{|l|}{ Channels of dissemination ${ }^{\mathrm{a}}$} \\
\hline $\begin{array}{l}\text { Publications (e.g. books } \\
\text { articles) }\end{array}$ & 0 & 0 & $\begin{array}{l}50.7 \\
(32)\end{array}$ & $20.9(13)$ & $\begin{array}{l}9.0 \\
(6)\end{array}$ & $\begin{array}{l}19.4 \\
(21)\end{array}$ \\
\hline Research reports & 0 & $1.5(1)$ & $\begin{array}{l}44.8 \\
(28)\end{array}$ & $20.9(13)$ & $\begin{array}{l}13.4 \\
(9)\end{array}$ & $\begin{array}{l}19.4 \\
(12)\end{array}$ \\
\hline $\begin{array}{l}\text { Policy reports/policy briefs/ } \\
\text { memos }\end{array}$ & 0 & 0 & $\begin{array}{l}22.4 \\
(14)\end{array}$ & $22.4(14)$ & $\begin{array}{l}28.4 \\
(18)\end{array}$ & $\begin{array}{l}26.9 \\
(17)\end{array}$ \\
\hline Traditional media articles & 0 & $4.5(3)$ & $\begin{array}{l}35.8 \\
(23)\end{array}$ & $20.9(13)$ & $\begin{array}{l}16.4 \\
(10)\end{array}$ & $\begin{array}{l}22.4 \\
(14)\end{array}$ \\
\hline $\begin{array}{l}\text { Blog pieces or entries in social } \\
\text { media }\end{array}$ & $3.0(2)$ & $4.5(3)$ & $\begin{array}{l}13.4 \\
(9)\end{array}$ & $19.4(12)$ & $\begin{array}{l}31.3 \\
(20)\end{array}$ & $\begin{array}{l}28.4 \\
(18)\end{array}$ \\
\hline $\begin{array}{l}\text { Training courses for policy } \\
\text { actors, administrative } \\
\text { organizations or other actors } \\
\text { and stakeholders } \\
\text { Modes of dissemination }\end{array}$ & 0 & $1.5(1)$ & $\begin{array}{l}20.9 \\
(13)\end{array}$ & $28.4(18)$ & $\begin{array}{l}26.9 \\
(17)\end{array}$ & $\begin{array}{l}22.4 \\
(14)\end{array}$ \\
\hline $\begin{array}{l}\text { Face to face with actor/ } \\
\text { organization }\end{array}$ & 0 & $6.0(4)$ & $\begin{array}{l}38.8 \\
(25)\end{array}$ & $29.9(19)$ & $\begin{array}{l}6.0 \\
(4)\end{array}$ & $\begin{array}{l}19.4 \\
(12)\end{array}$ \\
\hline $\begin{array}{l}\text { Over phone to actor/ } \\
\text { organization }\end{array}$ & $1.5(1)$ & $1.5(1)$ & $\begin{array}{l}25.4 \\
(16)\end{array}$ & $25.4(16)$ & $\begin{array}{l}22.4 \\
(14)\end{array}$ & $\begin{array}{l}23.9 \\
(15)\end{array}$ \\
\hline $\begin{array}{l}\text { By email or post to actor/ } \\
\text { organization }\end{array}$ & $3.0(2)$ & $1.5(1)$ & $\begin{array}{l}29.9 \\
(19)\end{array}$ & $25.4(16)$ & $\begin{array}{l}16.4 \\
(10)\end{array}$ & $\begin{array}{l}23.9 \\
(15)\end{array}$ \\
\hline $\begin{array}{l}\text { Via workshop or conference } \\
\text { (including event for non- } \\
\text { academic audiences) }\end{array}$ & 0 & $4.5(3)$ & $\begin{array}{l}46.3 \\
(29)\end{array}$ & $25.4(16)$ & $\begin{array}{l}9.0 \\
(6)\end{array}$ & $\begin{array}{l}14.0 \\
(9)\end{array}$ \\
\hline
\end{tabular}

Source: ProSEPS survey data

$N=63$

aQuestion: "Over the past three years, how frequently have you used any of the modes below (here above) to provide policy advice and/or consulting services?”

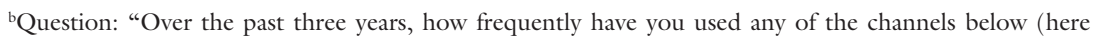
above) to provide policy advice and/or consulting services?"

area or on a specific issue. The political science community is more divided when it comes to normative views on policy advice and involvement in policymaking. More than $50 \%$ agree that political scientists should become involved in policymaking, while $42 \%$ disagree. However, what involvement (or non-involvement) in policymaking actually means is unclear. Thus, more than $60 \%$ agree that policy should be evidence-based and that 
Table 11.5 Governance level of (recipients of) advice $\%(N)$ - Norway
Table 11.6 Recipients of advisory activities \% $(N)$ - Norway

\begin{tabular}{lll}
\hline & Yes & No \\
\hline Sub-national level of governance & $37.3(24)$ & $67.2(40)$ \\
National level of governance & $79.1(50)$ & $20.9(13)$ \\
European level of governance & $9.0(6)$ & $91.0(58)$ \\
Trans-national/international & $11.9(8)$ & $88.1(56)$ \\
level of governance & & \\
\hline
\end{tabular}

Source: ProSEPS survey data

Notes: Question: "At which level of governance did you engage most frequently in policy advice or consulting activities during the last three years?"

$N=63$

\begin{tabular}{ll}
\hline Actors & $\%(N)$ \\
\hline $\begin{array}{l}\text { Interest groups in the } \\
\text { private and corporate }\end{array}$ & $32.8(21)$ \\
sector & \\
Think tanks & $22.4(14)$ \\
Advisory bodies & $37.3(24)$ \\
Civil servants & $71.6(46)$ \\
Political parties & $29.9(19)$ \\
Executive politicians & $35.8(23)$ \\
Legislative politicians & $29,9(19)$ \\
Other civil society & $44.8(28)$ \\
organizations and citizen & \\
groups & \\
International organizations & $31.3(20)$ \\
\hline
\end{tabular}

Source: ProSEPS survey data

Notes: Question: "With which actors did you engage in knowledge exchange, advisory or consulting activities during the last three years?" $N=63$

political scientists should provide evidence-based knowledge in arenas outside academia. Nevertheless, just a small minority agrees with the idea that political scientists should refrain for direct engagement with policy actors. 


\subsubsection{What Kinds of Advisory Activities Are Norwegian Political Scientists Engaged in, and How Often?}

In the survey, respondents were asked questions about their engagement in various types of advisory activities with policy actors.

The data indicate that Norwegian political scientists engage in advisory activities with policy actors quite often: more than 50\% engage in such activities at least once a year. They provide data and facts, analyse policy problems and evaluate policies and institutional arrangements. This activity also includes making value judgements and offering normative arguments. However, making normative arguments and value judgements is contested. More than one-third never offer normative arguments or value judgements; $16 \%$ never evaluate existing policies or institutional arrangements. Their responses could be interpreted in terms of the old normative distinction between "the political" and "the technical". Thus, different types of policy advisory activity can be placed along a continuum between the political and the technical. "Technical" advisory activities, such as the provision of data and facts, tend to prevail, while forecasts and normative judgements are the least prevalent and are regarded as the most problematic. The more we move towards the political end (providing evaluations and value judgements), the less prevalent and more contested the activities.

In principle, the combination of these factors indicates that just a small fraction of the political science community actively chooses to remain outside of the PAS. Political scientists taking the role of "pure academic" are rare. This suggests that roles and norms have been formed within political science, structuring scientific activities and perceptions so that the practical application of disciplinary knowledge in policy advice is highly acceptable. Only $5 \%$ fully agree that political scientists should refrain from direct contact with policymakers, and a mere $3 \%$ have never provided data or facts about policy or political phenomena to political actors. This illustrates the tight links between the academic community and the state. The Norwegian university was formed as a creature of the state for the state, designed to produce civil servants and the knowledge they required to fulfil their professional duties (Bleiklie et al., 2000). University professors were expected to assist and advice the state, offering expert knowledge in their respective specialized fields (Slagstad, 1998). Furthermore, the academic profession was, and remains, an integral part of the civil service, and its members enjoy the status of civil servants (Bleiklie \& Michelsen, 2008). This feature of the profession is highly significant. Civil servants have 
traditionally been considered special employees with dual loyalties, towards the state as employer, and to the nation as citizens of that nation (Seip, 1997). Formally speaking, Norwegian professors are situated within the boundaries of the state, but in functional terms they are "external" and independent, in the sense that institutional and individual autonomy has been afforded them by the state.

In the survey, respondents were asked questions about the frequency with which they provide policy advice and the channels they use for this purpose (see Table 11.4).

A small fraction use channels of policy advice on a weekly or monthly basis. This type of interaction normally takes place through face-to-face communications with policy actors/organizations, through workshops/ events or through traditional media articles, blogs or social media writings. A large majority of political scientists provide policy advice at least once a year, and the main channels they use are publications (books and articles), research reports and traditional media articles, followed by faceto-face encounters, phone conversations and emails.

Most knowledge exchange, advisory or consultancy activities take place in settings characterized by a mixture of informal and formal elements $(40 \%)$ or in mainly formal settings $(28 \%)$. Just $3 \%$ declared that they were active in purely formal settings. Hence, these informal exchanges and discussions are very much prevalent.

\subsubsection{At What Level, and with Which Actors, Do Norwegian Political Scientists Engage in Advisory Activities?}

Data from the survey indicate that the national level is the major arena for the provision of policy advice. Almost $80 \%$ engage at this level. This corroborates the national orientation of Norwegian political science. However, Norwegian political scientists are generally also heavily involved in policy issues and in the provision of policy advice at the sub-national level of governance $(37.7 \%)$. This shows that the Norwegian politicoadministrative system provides access points for the provision of political advice at both the local and national levels. Offering policy advice at European and international levels seems less prevalent, comprising about $21 \%$ of respondents.

Norwegian political scientists engage with a variety of different actors (see Table 11.6). The percentage of political scientists who have been engaged in advisory bodies corroborates the general tendency of increased 
expert representation by political scientists in such bodies. A total of $37.3 \%$ of the respondents have engaged with advisory bodies over the last three years. Twice as many have engaged with civil servants in knowledge exchange, advisory or consulting activities over the last three years. Thirty per cent have engaged with political parties and $36 \%$ with executive politicians; $33 \%$ have engaged in exchanging knowledge or providing political advice with interest groups in the private and corporate sectors, and $45 \%$ with civil society organizations and citizen groups; $22 \%$ of the respondents have engaged with think tanks. Like interest groups and civil society organizations, "think tanks" represent civil society. They are situated outside the state, and they provide public decision-makers with knowledge and arguments. This number is quite high considering that advocacy think tanks in Norway are something of a recent phenomenon. Norwegian think tanks are characterized by their partisan and non-academic profile (Christensen \& Holst, 2017). For the most part they have an explicit ideological profile, covering the whole political spectrum from left to right. The applied research institutes are not usually regarded as think tanks (Ibid.). Through their main activities, such as publications (pamphlets, reports, policy briefs and the occasional book), seminars, and debates, they engage in the dissemination of knowledge, political debate, and the provision of policy advice (Bjerke, 2012). They are much more active in disseminating knowledge rather than in producing it, and recruitment patterns are based more on political affiliation rather than on academic merit. However, Norwegian media contributors from think tanks are normally presented as independent experts (Bjerke, 2012). Their standing as independent expert organizations is not very high compared to that of universities and applied research institutions, and they depend on the more established institutions of academic expertise. Think tanks have regularly engaged with academics, often social scientists from the universities, and some of these have also found think tank forums to be rewarding as an alternative to regular academic and consultative channels. As far as research goes however, they can be considered as "second-hand stores" rather than as the producers of knowledge, and research results are as a rule explored, systematized and strategically exploited for partisan political purposes. 


\subsection{The Provision of Academic Expert Advice Through Advisory Bodies and Commissions}

One important corporatist venue for the provision of policy advice is that of advisory bodies and commissions. Commissions are governmental advisory bodies that operate as decision-making groups on a consensual basis. The significance of the role played by commissions in the Nordic countries has led scholars to characterize them as a core element of the "Nordic model of government" (Arter, 2008). The Norwegian commission system is far more extensive than those in countries with a Westminster-type government, for example (Craft \& Halligan, 2017). Typically for the Norwegian neo-corporatist variant of PAS, these bodies find themselves at the intersection of three arenas, rather than at the government/academic arena intersection or the government/societal intersection. Thus, they closely connect the state, academia and corporatist interests in the provision of policy advice.

Here we want to concentrate on ad hoc advisory commissions and the representation of academic experts, civil servants and organized interests. Academic experts wield increasing influence on public policymaking (Tellmann, 2016; Christensen \& Hesstvedt, 2019; Christensen et al., 2018, Christensen \& Holst, 2017). Available figures show clear trends in the participation of academics on commissions. Firstly, the total number of academics on commissions has increased gradually, from $7 \%$ in the 1970 s to $26 \%$ in the last decade. Thus, expert advice has become increasingly important within the corporatist channel, in public commissions and on temporary advisory boards, although organized interests are still important actors (Christensen \& Holst, 2017).

During this period, the position of social scientists in general, and of political scientists in particular, has been considerably strengthened.

Economists are the largest academic group present on public commissions, followed by social scientists. The latter group has grown strongly, rising from $10 \%$ of total academic members in the 1970 s to $27 \%$ in the 2010 s. Economics and other social sciences together represented the professional background of more than half of all academic members of public commissions in 2010. Political scientists and sociologists comprised approximately $70 \%$ of all social science members. In comparison, representatives of the natural sciences, medicine, technology and engineering have significantly fallen in number. This development is remarkable considering that political scientists were struggling to make their mark in policy 
advisory processes during the 1970s (Kuhnle \& Rokkan, 1977). An early study of members of public commissions showed that political scientists were rarely called upon for advice. In fact, only 15 cases were found where a political scientist was a member of, or a consultant to, a public commission.

The increased representation of political scientists could reflect the fact that the position of political scientists in the bureaucracy has changed dramatically over time. While most candidates previously found employment in government administrations outside of the central bureaucracy, or with lower-level administrations (Kuhnle \& Rokkan, 1977), a survey conducted in 2018 (thanks to Per Lægreid for providing this material) gives a completely different picture (Christensen et al., 2018). Political scientists now (in 2018) constitute one of the three largest academic groups in Norwegian ministries, together with lawyers and economists. Furthermore, political scientists are distributed across all ministries. According to Christensen and Lxgreid (2008), technical competence in general is held in high regard in the civil service. In their 2005 survey, $80 \%$ of all civil servants stated that technical knowledge was important or very important in their own position. The ability to give good and reliable policy advice was slightly less appreciated, as $65 \%$ declared that this was important in their position. This ability was far more common in ministries than in central agencies (Ibid.) In general, social scientists (political scientists included) score high on policy advice, boundary-spanning skills and implementation abilities but low on technical knowledge. They also score highest on reform-related areas of competence. This may imply not only that their educational background is more conducive to developing this kind of competence but also that it is more closely related to the design and development of different aspects of administrative policy rather than to the technical contents of these policies (Ibid.).

\subsection{RCN and Programme Research: A New INTERFACE FOR EXPERT ADVICE}

Another important arena intersection for the provision of policy advice is the Norwegian Research Council ( $\mathrm{RCN})$, once again at the heart of the PAS model in Fig. 11.1. Here, the state's need for useful research knowledge and academic research competence is brought together under one roof. The RCN serves as an advisory body on research policy issues, 


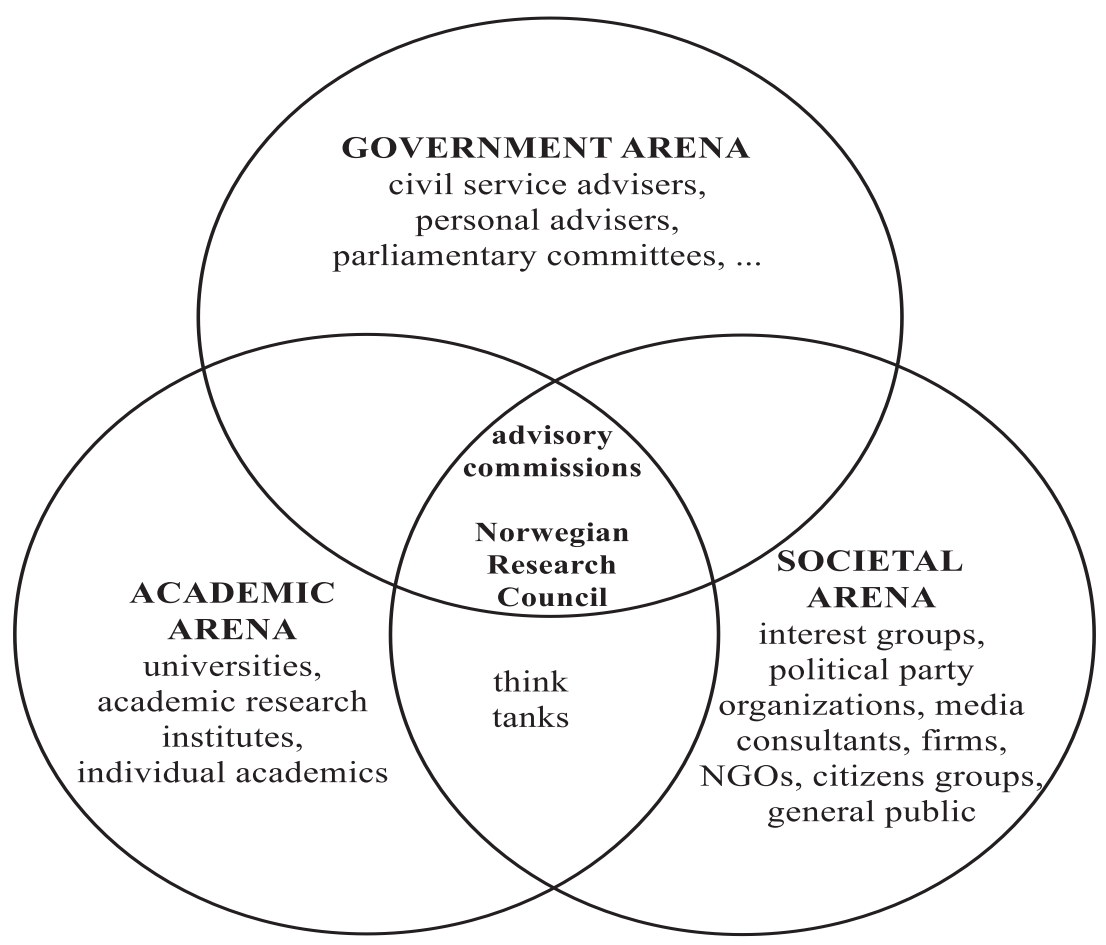

Fig. 11.1 Expert advice at the heart of the policy advisory systems modelNorway. (Source: Adapted from Blum and Brans (2017) [see Chap. 2, this volume])

identifies research needs and recommends national research priorities. The various ministries all provide resources for research through the RCN, and they are responsible for steering research in their particular fields. When four existing research councils merged in 1995, the resulting new council was an unusual creature in an international context, in that it encompassed both basic and applied research (Skoie, 2005). The merger was justified as an attempt to break down the sharp division between basic and applied research and to situate all research within a context of application (Guldbrandsen, 2005).

In this new structure, programme research evolved as a core component mediating between basic and applied research (Mathisen, 1989; Emblem, 2010). In this space, politicization processes created fresh room for more "applied" programme research in basic areas, where researcher 
autonomy and academic self-governance previously had been the rule. Policy considerations and policy utility became the normal basis for programme development and funding (Sejersted, 1991). The old division of labour between the university sector and the policy-oriented institute sector was reconfigured. The applied research institutes were now regarded as an integral part of the academic research community. On the other hand, programme research also created new opportunities for universities to engage in problem-oriented research based on relatively broad, longterm research programmes.

The result was a series of relatively specialized programmes, funding opportunities and patterns of representation. A study of the composition of programme boards in the period 2000-2010 $(N=797)$ suggests that on average researchers represent the majority of board members-some $55 \%$ - while the "users" comprise a large minority of $45 \%$ (Bjerke, 2012). A similar percentage is recruited from the higher education sector, while $8 \%$ of board members come from the applied institute sector. Civil servants or representatives of organized interests make up $22 \%$, while $8 \%$ come from the business sector. The natural sciences, technology and engineering and medicine/health professions enjoyed strong representation in this arrangement. The social sciences, law and the humanities, on the other hand, were not as strongly represented. Most programmes pertaining to political science do not address questions limited to specific disciplines but comprise broader sets of issues that are often open to interdisciplinary cooperation, sometimes also involving co-production and "users as co-researchers". Available data from the Bjerke (2012) study suggest that political scientists are not well represented on RCN programme boards. Estimates indicate that $3-5 \%$ of all board members trained as political scientists. Furthermore, political scientists tend to be concentrated in programmes related to issues of democracy, education, the welfare state, welfare services and EU-related research.

The system of relatively fine-grained programmes organized around a fairly predictable division of labour within the RCN has paved the way for networks connecting policy problems, research problems, researchers, civil servants and administrators from the various segments of the political administrative system. The programme boards are significantly involved in providing venues, conferences and workshops, where policymakers and civil servants from the ministry and agencies, organized interests, researchers and other stakeholders concerned with a specific research field can meet. These activities and venues involve a small core of political science 
researchers funded by the RCN as well as other researchers engaged in various different policy fields. This configuration of processes, values, arenas, actors and outcomes illustrates important institutional conditions for the widespread notion of policy advice provision held among Norwegian political scientists in the ProSEPS survey.

The Norwegian PAS and its various arenas have provided important institutional conditions for the widespread notion of policy advice held by Norwegian political scientists. The data profiles associated with each ideal type indicate that two of the four ideal typical roles are hardly represented among Norway's political scientists (see Table 11.7).

Public intellectuals as defined and measured here are rarely encountered. Moreover, the relative scarcity of public intellectuals in Norwegian public life has been discussed in the Norwegian media in recent years. We were able to identify two people who have been active in this role, one of whom died in 2017, and the other who retired in 2016. In the survey, no Norwegian political scientist seemed to fit the description of the "public intellectual". A small group of "pure academics" emerged however. Nevertheless, the concentration of political scientists (almost 90\%) in two of the four role categories is overwhelming.

This leaves us with the other two ideal types: the "expert" and the "opinionating scholar". Ideal types are abstract utopian, one-dimensional methodological tools. They are simplified, logical constructions emphasizing different elements. Measured by the condensation of indicators and results in the survey, $55 \%$ of Norwegian political scientists can be classified as opinionating scholars, while almost $35 \%$ can be classified as experts. The percentage of political scientists who consider engagement in advisory

Table 11.7 Ideal typical roles of political scientists with regard to policy advice $\%(N)$-Norway/Europe

\begin{tabular}{lccc}
\hline Ideal type & Total number in Norway & Norway (\%) & Europe (\%) \\
\hline Pure academic & 7 & 10.4 & 19.6 \\
Expert & 23 & 34.3 & 28.2 \\
Opinionating scholar & 37 & 55.2 & 47.8 \\
Public intellectual & 0 & 0.0 & 4.3 \\
Total & 67 & 99.9 & 99.9 \\
\hline
\end{tabular}

Source: ProSEPS survey data

Notes: Types operationalized on the basis of content of advice and frequency. See Chap. 2

$N=63$ 
activities as a duty, as well as a part of their role (more than 90\%), testifies to the weight of public debate activities and the high opinionating scholar score, as does the frequency of this type of engagement. On the other hand, the survey results also reveal that $70 \%$ of all political scientists engage with civil servants and that "technical" advisory activities, such as the provision of data and facts, are prevalent and considered appropriate, while forecasting and normative judgements are less prevalent and regarded as more problematic. Engaging in public debate is seen by most to be an obligation; however, the preferred form of engagement underlines the strong status of expertise and a reluctance to engage in partisan political debate and arguments.

\subsection{CONCLUSION}

Norwegian political science has emerged, and has derived its core characteristics, from the politico-administrative system in which it is historically embedded. Political science became tied to the state through the provision of higher education programmes, through the development of political advisory systems, and through research. This also shaped how academic political scientists perceived their discipline and policy advice and how they provide advice and participate in policy advisory activities. As the discipline grew and diversified, Norwegian political science emerged as empirically solid, policy-oriented and with a nationally oriented research agenda. The academic experts in the discipline tend towards contributing to policymaking and at the core of the discipline lies a strong orientation towards democracy.

Norwegian political scientists engage in a wide range of advisory activities with policy actors, and in particular with civil servants. In this arena they often engage with their own kind, since political scientists represent a major educational category in Norwegian ministries. From a modest basis in local government, political scientists have since become one of the three largest groups in Norway's ministries, together with lawyers and economists. Political scientists apparently do not represent technical advice in the traditional sense. Instead, a different type of advice is provided, focusing more on reform-related policy issues, boundary-spanning skills, and execution competence. While this could imply that the educational background of political scientists is more conducive to developing this kind competence, it may also mean that it is more closely related to the design and development of different aspects of administrative policy than to the 
technical contents of these policies. These features have an interesting parallel in their preferred types of engagement: the provision of data and facts, the analysis of policy problems and the assessment of policies and institutional arrangements.

Within the architecture of the Norwegian PAS, the corporatist system represents an additional focus for academic political scientists with regard to the provision of policy advice. The corporatist arenas illustrate the interaction of politicization and de-politicization in the formation of overlapping arenas and institutions. This does not necessarily imply that Norwegian political science has evolved into an architectonic discipline, based on policy relevance and the provision of policy solutions. Norwegian academic political scientists are more interested in policy problems than solutions. While political scientists are distributed across all ministries, they tend to be concentrated in certain specific arenas rather than in others. While academic political scientists have achieved a strong position in the field of temporary advisory boards, their position in the RCN is concentrated on social science programmes and is considerably weaker.

Norwegian political scientists engage in a broad range of policy advisory activities. Engaging in public debate is generally seen as an obligation by most political scientists and as an integral part of their role. More than two-thirds have taken part in public debate in the media over the last three years. Measured by the ideal typical advisory roles suggested, the available data point in two directions: the roles of "the opinionating scholar" and "the technical expert". One of the commendable aspects of the ProSEPS project is the extension and integration of sets of variables that have been brought to bear on the provision of expert policy advice. We can now get a far more nuanced picture of the policy advisory roles and activities than previous research allowed for. The data provide a picture of academic political scientists that is a far cry from representations of the allegedly isolated "ivory tower" of the university. This approach provides a new abundance of policy advisory activities, as well as new roles and role-sets for the shaping of various types of policy advice. However, the choice of ideal types is highly theoretical, and several questions remain regarding their construction and the interpretation of observations. Norwegian political scientists seem to engage extensively in public debate. But does extensive involvement in public debate necessarily make academic political scientists opinionating scholars? Does preoccupation with policy problems necessarily imply getting involved in the provision of policy solutions and "what works", as implied in the expert category? Description is not 
neutral. The results testify to the increasing complexity and ambiguity of policy advice. This allows for different interpretations, where some of the implications might be clearly normative. It also points to the fact that razor sharp distinctions between role types are difficult to make and that the categories may be blurred at times. The Norwegian case of political science policy advice suggests the prevalence of a curious mixture of roles and orientations, combining and aligning features associated with "the opinionating scholar" and "the expert" in actual practices and regularities, where problem orientations in both areas seem more important than technical solutions.

\section{REFERENCES}

Arter, D. (2008). Scandinavian politics today (2nd ed.). Manchester University Press.

Askim, J., Karlsen, R., \& Kolltveit, K. (2014). Statssekretærer i norsk politikk: De oversette maktutøverne [State secretaries in Norwegian politics: The overlooked power-wielders]. Norsk Statsvitenskapelig Tidsskrift, 30(4), 233-255.

Baldersheim, H., \& Rose, L. E. (2010). The politics of boundaries and borders. Palgrave Macmillan.

Bjerke C. (2012). Konsensus eller interessekamp? Sammensetning og tildelingsmønstre $i$ programstyrene til Norges Forskningsraid: en kvantitativ analyse av governance $i$ norsk forskningspolitikk. Master's degree thesis, Department of Administration and Organization Theory, University of Bergen.

Bleiklie, I., Høstaker, R., \& Vabø, A. (2000). Policy and practice in higher education: Reforming Norwegian Universities. Jessica Kingsley.

Bleiklie, I. and Michelsen, S. (2008). The university as enterprise and academic co-determination. In Amaral, A. Bleiklie, I. and Musselin, C. (eds.) From governance to identity. : Springer.

Bleiklie, I., \& Michelsen, S. (2013). Comparing higher education policies in europe -Structures and outputs in eight countries. Higher Education, 65(1), 113-133.

Blum, S., \& Brans, M. (2017). Academic policy analysis and research utilization for policymaking. In M. Brans, I. Geva-May, \& M. Howlett (Eds.), Routledge handbook of comparative policy analysis (pp. 341-359). Routledge.

Christensen, J., \& Hesstvedt, S. (2019). Expertisation or greater representation? Evidence from Norwegian advisory commissions. European Politics and Society, $20,83-100$.

Christensen, J., \& Holst, C. (2017). Advisory commissions, academic expertise, and democratic legitimacy: The case of Norway. Science and Public Policy, $44(6), 821-833$. 
Christensen, T., Egeberg, M., Lxgreid, P., \& Trondal, J. (2018). Sentralforvaltningen. Stabilitet og endring gjennom $40 \mathrm{ar}$. Universitetsforlaget.

Christensen, T., \& Lxgreid P. (2008). Administrative reforms and competence in central government organizations. Stein Rokkan Centre for Social Studies, Working Paper 7.

Craft, J., \& Halligan, J. (2017). Assessing 30 years of Westminster policy advisory system experience. Policy Sciences, 50, 47-62.

Craft, J., \& Howlett, M. (2013). The dual dynamics of policy advisory systems: The impact of externalization and politicization on policy advice. Policy and Society, 32(3), 187-197.

Egeberg, M., Olsen, J. P., \& Sxtren, H. (1978). Organisasjonssamfunnet og den segmenterte stat. In J. P. Olsen (Ed.), Politisk Organisering. Universitetsforlaget.

Emblem, T. (2010). Kampen om FMD. En forskningspolitisk analyse av Fondet for markeds-og distribusjonsforskning 1971-1989. Dr.Philos Thesis. University of Bergen.

Espeli, H. (1999). Lobbyvirksombet på Stortinget. TANO Aschehoug.

Guldbrandsen, M. (2005). Tensions in the research council-research community relationship. Science and Public Policy, 32(3), 199-209.

Hammerstein, N. (2011). Social science, history and law. In W. Rüegg (Ed.), $A$ history of the university in Europe volume IV universities since 1945. Cambridge University Press.

Jacobsen, K. D. (1960). Lojalitet, nøytralitet og faglig uavhengighet. Tidsskrift for Samfunnsforskning, 1, 231-248.

Jacobsen, K. D. (1964). Teknisk hjelp og politisk struktur. Universitetsforlaget.

Kuhnle, S. (1986). Linjer i norsk statsvitenskap: institusjonell differensiering og forskningsekspansjon. In I. S. Kuhnle (Ed.), Det politiske samfunn. Linjer $i$ norsk statsvitenskap (pp. 47-68). Tano.

Kuhnle, S., \& Rokkan, S. (1977). The growth of the profession: Norway. Scandinavian Political Studies, 12.

Mathisen, W. C. (1989). Mellom akademia og marked. Styring av forskning $i$ instituttsektoren. NAVFs utredningsinstitutt. Meldning 1989, 2.

Olsen, J. P. (1983). Organized democracy: Political institutions in a welfare stateThe case of Norway. Universitetsforlaget.

Olsen, J. P. (2012). Hvor går statsvitenskapen? Norsk statsvitenskapelig tidsskrift, $28(3), 125-151$.

Painter, M., \& Peters, B. G. (2010a). The analysis of administrative traditions. In M. Painter \& G. P. Peters (Eds.), Tradition and public administration. Palgrave Macmillan.

Painter, M., \& Peters, B. G. (2010b). Administrative traditions in comparative perspective: Families, groups and hybrids. In M. Painter \& B. G. Peters (Eds.), Tradition and public administration. Palgrave Macmillan.

Peters, B.G. (2001). The future of governing. University of Kansas Press. 
Pollitt, C., \& Bouckaert, G. (2004). Public management reform. A comparative analysis, (2nd edition). Oxford University Press.

Rommetvedt, H. (2005). Norway: Resources count, but votes decide? From neocorporatist representation to neo-pluralist parliamentarism. West European Politics, 28(4), 740-763.

SAMEVAL. (2018). Evaluation of the Social Sciences in Norway. Oslo: The Research Council of Norway.

Seip, Å. A. (1997). Rett til å forbandle. En studie $i$ statstjenestemennenes forhandlingsrett $i$ Norge og Sverige 1910-1965. Doktoravhandling. FAFO, 1997.

Sejersted, F. (1991). Refleksjoner om forskningens samfunnsnytte. ArbeidsnotatWorking Paper. TMV 31. Oslo: Senter for teknologi og menneskelige verdier.

Skoie, H. (2005). Norsk forskningspolitikk $i$ etterkrigstiden. Cappelen Akademisk Forlag.

Slagstad, R. (1998). De nasjonale strateger. Pax Forlag.

Starr, P., \& Immergut, E. (1987). Health care and the boundaries of politics. In C. S. Maier (Ed.), Changing boundaries of the political. Cambridge University Press.

Streeck, W., \& Schmitter, P. C. (1985). Community, market, state-and associations? The prospective contribution of interest governance to social order. In W. Streeck \& P. C. Schmitter (Eds.), Private interest government. Beyond market and state (SAGE-series in neo-corporatism). Sage Publications.

Tellmann, S. M. (2016). Experts in public policymaking: Influential, yet constrained. Doctoral Thesis, Oslo and Akershus University College of Applied Sciences.

Thue, F. W., \& Helsvig, K. G. (2011). Universitetet $i$ Oslo 1945-1975. Den store transformasjonen. UNIPUB.

Underdal, A. (2007). Norsk statsvitenskap 60 år: Hvor står vi, hvor går vi. Norsk Statsvitenskapelig Tidsskrift, 23(3), 244-266.

Verhoest, K., Roness, P. G., Verschure, B., Rubecksen, K., \& NacCarhaigh, M. (2010). Autonomy and control in state agencies. Palgrave Macmillan.

Weber, M. (2013). Economy and society. University of California Press. 
Open Access This chapter is licensed under the terms of the Creative Commons Attribution 4.0 International License (http://creativecommons.org/licenses/ by $/ 4.0 /$ ), which permits use, sharing, adaptation, distribution and reproduction in any medium or format, as long as you give appropriate credit to the original author(s) and the source, provide a link to the Creative Commons licence and indicate if changes were made.

The images or other third party material in this chapter are included in the chapter's Creative Commons licence, unless indicated otherwise in a credit line to the material. If material is not included in the chapter's Creative Commons licence and your intended use is not permitted by statutory regulation or exceeds the permitted use, you will need to obtain permission directly from the copyright holder. 